$2019 \uparrow$ Volume $22 \uparrow$ Issue $3 \uparrow 5-18$

DOI: $10.33223 / \mathrm{epj} / 111757$

\title{
The proposal of an energy mix in the context of changes in Poland's energy policy
}

ABSTRACT: The future and the development of power industry are the one of the major issues in the domestic and global policy. The impact of the power sector on the earth climate changes and the attention for sufficient funds of energy in the following years are the primary challenges which the power industry is facing. The article delineates the current state of the domestic sector of energy production. In the prospect of the next few years, it will draw on conventional power engineering nevertheless, with the growing involvement of renewable energy sources. However, it is important to develop the new energy strategy, which will point the direction of domestic energy production sector changes. What is more relevant, the new legal regulations connected with environmental protection will definitely restrict using fossil fuels in the power industry. In addition, the paper discusses the most important aspects involved in creating a country's energy mix. The first aspect is the current state of the energy sector in Poland, i.e. the percentage of particular technologies in the present power and electrical energy balances, the technical state of the manufacturing sector's infrastructure. Based on historical data of Polskie Sieci Elektroenergetyczne SA regarding the energy consumption and demand, a mathematical estimation for electricity demand and its consumption forecast was performed. The obtained forecasts were

Corresponding Author: Radosław Szczerbowski; e-mail: szczerbowski@poczta.fm

${ }^{1}$ Institute of Electrical Power Engineering, Poznan University of Technology, Poznań, Poland; ORCID iD: 00000001-8262-683X; e-mail: kornobisdominika@wp.pl

2 Poznan University of Technology, Poznań, Poland; ORCID iD: 0000-0002-9228-1123; e-mail: szczerbowski@, poczta.fm

2019. The Author(s). This is an open-access article distributed under the terms of the Creative Commons Attribution-ShareAlike International License (CC BY-SA 4.0, http://creativecommons.org/licenses/by-sa/4.0/), which permits use, distribution, and reproduction in any medium, provided that the Article is properly cited. 
then used to conduct a simulation of power and energy demand fulfillment in the national power system. Finally, several possible scenarios were presented, taking different factors affecting the energy sector in Poland into consideration.

KEYWORDS: energy policy, energy safety, energy mix

\section{Introduction}

The primary role of each country is ensuring its citizens safety in every parts of their lives including energy security. An enormously important task is ensuring the stability of functioning of the electricity and the fuel sector. Until 1990, over $90 \%$ of the share in electricity production came from coal-fired power plants. The issues connected with the negative effects which influenced the environment through the energy sector were secondary. Large coal deposits and the stability of power sector based on coal sources did not tend to source energy diversification. After Poland joined the EU in 2004 the perspective of the energy sector changed. In 2008, the provisions of the Energy and Climate Package were adopted. Climate protection was one of the main goals of creating the Polish energy mix. The share of coal in the energy balance is still on a very high level but we have to remember that the coal reserves are currently decreasing. If we want to adjust Poland's energy mix to EU obligations regarding $\mathrm{CO}_{2}$ reductions and increase in renewable energy sources use, we have to take steps to change the structure of production. This task is quite complicated but taking the wide economic, environmental and social contests into consideration makes us aware that additional factors have to be taken into account. Domestic energy security and efficient energy use are one of the most paramount and important factors. They tend to successively limit the growing request on electricity.

Increasing care about the climate and an attempt to reduce global warming have allowed us to see the future of energy in renewable energy sources. The arrangements for the Conference of Participants of the United Nations in connection with climate changes and the new EU legal records on harmful gases emission has resulted in the number of new investments in the development of the conventional energy sector to decrease dramatically. At present, more and more countries are moving away from, or in the next few years are going to move away from coal as the primary source of power generation. Poland doesn't have a current, long-term and clear vision of the development of this sector, and lignite and hard coal still play a major role in ensuring energy security. In accordance with the provisions of the Strategy for Responsible Development until 2020 (Strategy 2017), it is necessary to rebuild the production potential of electricity generation sources based on the raw materials available in the country. Therefore, it can be concluded on the basis of this document that in the coming years, coal as an energy fuel, will still be of great importance in shaping the domestic production potential. The profitability of energy production from this resource will depend, to a large extent, on the prices of emission allowances, which was 
already pointed out in the article (Olkuski 2015), and since then the prices of allowances have increased several times and are still growing. However, the question remains how the strategy for the development of the power system will look in the next years (Szczerbowski and Ceran 2017).

The energy mix, which also provides a beneficial energy production structure, provides coverage to the present day in the mode of economic energy. The optimal energy mix for the economy of a given country is one that provides enough power and energy in the power system and, at the same time, the lowest economic cost of its production. In order to propose the most favorable energy mix, the current state of the national energy sector should be analyzed in advance in order to forecast the demand for power and energy, and take the objectives of the state energy policy and other factors affecting the development of the domestic energy sector into account (including economic and environmental) (Janusz et al. 2017). In creating an energy mix, it should be remembered that each energy generation technology has a different annual working time, which means that not every proposal to cover the power demand in the system will ensure the coverage of electricity demand at the same time.

\section{The National Power System}

The Polish energy system is one of the largest in Europe, and the installed capacity in the National Power System (NPS) from the data at the end of 2018 is 45,939 MW. The maximum national demand for power in 2018 amounted to $26,448 \mathrm{MW}$. In comparison with data at the end of 2017, there was an increase of approximately $2.5 \mathrm{GW}$ of installed capacity, of which a significant part is the installed capacity in coal-fired power plants. The main source of energy production in Poland are coal-fired power plants. Currently, the installed power from main activity power plants is about $70 \%$ of the installed capacity. On the other hand, the share of renewable energy sources (excluding hydroelectric power plants) in the balance of installed capacity at the end of 2018 was about $14.5 \%$ (wind and other renewable), and energy production from these sources exceeded 7\%. Tables 1 and 2 present basic data on the current situation in the NPS. As you can see, the total installed capacity in coal-fired power plants is over $30 \mathrm{GW}$, which is over $69 \%$ of the installed capacity, while the electricity production in these sources is over $79 \%$. It is also worth paying attention to the fact that since 2016 a need to balance the shortage of electricity in the NPS with imports from neighboring countries has arisen, and this tendency is of increasing nature. This has a special significance in considering whether we will be able to adapt our energy mix to the requirements set by the European Union in the $3 \times 20$ package, which imposes a commitment to increase the share of energy from RES (not the share of installed capacity) to $15 \%$ on us.

The power generation sector in our country is based on production in outdated power plants and combined heat and power plants. As shown in Fig. 1, the largest share with regard to the installed power is in power plants (and combined heat and power plants), the turbine sets and boilers of which are over 30 years of age. It is assumed that the lifetime of a coal-fired power plant 
TABLE 1. The present state of the installed power in the National Power System (data as at 2018-12-31)

TABELA 1. Stan obecny struktury mocy zainstalowanej w Krajowym Systemie Elektroenergetycznym (dane na 31.12.2018)

\begin{tabular}{|l|c|c|c|c|}
\hline \multicolumn{1}{|c|}{ Specification } & 31.12 .2015 & 31.12 .2016 & 31.12 .2017 & 31.12 .2018 \\
\hline Main activity power plants [MW] & 32,317 & 32,318 & 34,268 & 36,638 \\
\hline Hydro power plants [MW] & 2,290 & 2,292 & 2,328 & 2,341 \\
\hline Thermal power plants, of which [MW]: & 30,027 & 30,025 & 31,939 & 34,296 \\
\hline Coal power plants [MW] & 19,266 & 19,083 & 20,247 & 23,215 \\
\hline Lignite power plants [MW] & 9,290 & 9,332 & 9,352 & 8,752 \\
\hline Natural gas power plant [MW] & 1,472 & 1,610 & 2,341 & 2,330 \\
\hline Wind power plants and other renewables [MW] & 5,384 & 5,706 & 6,341 & 6,621 \\
\hline Industrial power plants [MW] & 2,821 & 2,828 & 2,813 & 2,680 \\
\hline Total [MW] & 40,522 & 40,852 & 43,421 & 45,939 \\
\hline Centrally Dispatched Generating Unit [MW] & 25,255 & 25,097 & 26,952 & 29,128 \\
\hline Non-Centrally Dispatched Generating Unit [MW] & 15,268 & 15,755 & 16,470 & 16,811 \\
\hline
\end{tabular}

Source: own study based on (PSE 2019).

TABLE 2. The present state of the structure of electricity generation in the National Power System (data as at 2018-12-31)

TABELA 2. Stan obecny struktury produkcji energii elektrycznej

w Krajowym Systemie Elektroenergetycznym (dane na 31.12.2018)

\begin{tabular}{|l|r|r|r|r|}
\hline \multicolumn{1}{|c|}{ Specification } & \multicolumn{1}{c|}{2015} & \multicolumn{1}{c|}{2016} & \multicolumn{1}{c|}{2017} & \multicolumn{1}{c|}{2018} \\
\hline Main activity power plants [GWh] & 141,901 & 140,727 & 141,790 & 143,234 \\
\hline Hydro power plants [GWh] & 2,261 & 2,399 & 2,767 & 2,197 \\
\hline Thermal power plants, of which [GWh]: & 139,640 & 138,328 & 139,023 & 141,037 \\
\hline \multicolumn{1}{|c|}{ Coal power plants [GWh] } & 81,883 & 81,348 & 79,868 & 82,375 \\
\hline Lignite power plants [GWh] & 53,564 & 51,204 & 51,983 & 49,072 \\
\hline Natural gas power plant [GWh] & 4,193 & 5,776 & 7,172 & 9,590 \\
\hline Wind power plants and other renewables [GWh] & 10,114 & 11,769 & 14,005 & 11,958 \\
\hline Industrial power plants [GWh] & 9,757 & 10,130 & 10,057 & 10,022 \\
\hline Energy generation [GWh] & 161,772 & 162,626 & 165,852 & 165,214 \\
\hline Energy consumption [GWh] & 161,438 & 164,625 & 168,139 & 170,932 \\
\hline Foreign exchange balance [GWh] & -334 & 1,999 & 2,287 & 5,718 \\
\hline
\end{tabular}

Source: own study based on (PSE 2019). 


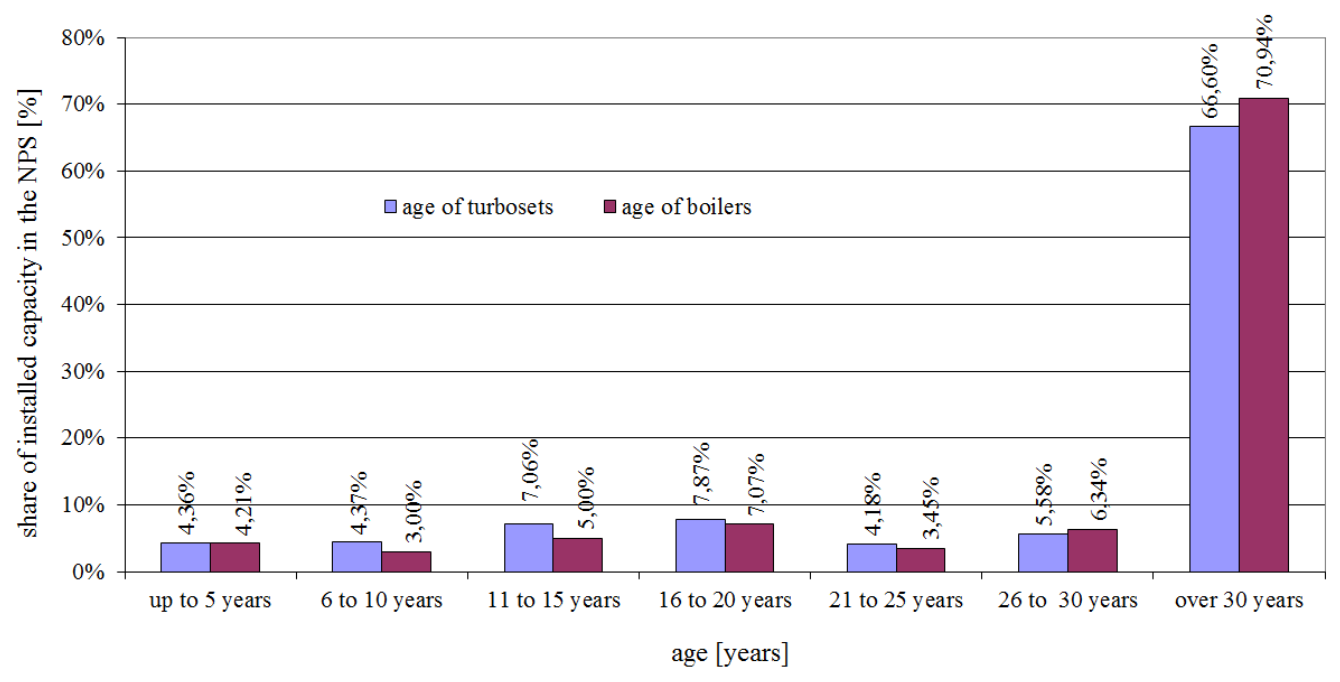

Fig. 1. Age structure of turbine sets and boilers in relation to the power installed in the NPS Source: own study based on (Report 2017)

Rys. 1. Struktura wiekowa turbozespołów i kotłów w odniesieniu do mocy zainstalowanej w KSE

is about 40 years. Admittedly, the factor that affects such a large share of "old" thermal power plants is their constant modernization, which affects the extension of their lifetime.

The age structure of the National Power System means that in the years 2017-2019, power units in: Adamów Power Plant $(5 \times 120 \mathrm{MW})$, Bełchatów $(1 \times 370 \mathrm{MW})$ have been withdrawn from use, and soon next blocks will join them: Bełchatów $(1 \times 370 \mathrm{MW})$, Łagisza $(120 \mathrm{MW})$, Łaziska (2×125 MW), Siersza (120 MW) and Stalowa Wola (120 MW) (Assurance 2014). According to the scenario of cumulative withdrawals of existing generating units presented by PSE SA, which also assumes withdrawals due to the planned implementation of new emission standards (Best Available Techniques) (Best 2016), it will be necessary to exclude over $20 \mathrm{GW}$ of generating sources by 2035 (Plan 2015). At present in Poland, several investments connected with building new generation capacities using hard coal, lignite and gas as fuel are underway. The prospect of decommissioning significant generation capacities and the uncertainty of launching planned investment projects and the current conditions may imply a risk of unstable work of the NPS and the possibility of satisfying the future energy demand in the nearest future.

According to the forecasts of power and energy demand in the near future, the national energy system may have problems with maintaining a balance. The forecast for the coming years assumes an increase in demand for power for both the summer and winter summits. Due to the necessity to withdraw significant power from the power system, both due to the age of the units and the problem of fulfilling environmental obligations, reconstructing and building new generation capacities will be necessary (Table 3 ). The required increase in installed capacity in the NPS will be related to this (Table 4). 
TABLE 3. Cumulative withdrawals of power in existing CDGU (Centrally Dispatched Generating Units) up to 2035 in the BAT modernization scenario and BAT recall scenario

TABELA 3. Skumulowane wielkości wycofań mocy w istniejących JWCD cieplnych do $2035 \mathrm{r}$. w scenariuszu modernizacyjnym BAT oraz scenariuszu wycofań BAT

\begin{tabular}{|l|c|c|c|c|}
\hline & until 2020 & until 2025 & until 2030 & until 2035 \\
\hline $\begin{array}{l}\text { Cumulative phase-out of thermal CDGU capacity [MW] - } \\
\text { modernization scenario }\end{array}$ & 2,985 & 3,410 & 5,668 & 14,675 \\
\hline $\begin{array}{l}\text { Cumulative phase-out of thermal CDGU capacity [MW] - } \\
\text { BAT phase-out scenario }\end{array}$ & 4,960 & 9,175 & 16,560 & 20,262 \\
\hline
\end{tabular}

Source: own study based on (Report 2017).

TABLE 4. Power requirement for BAT upgrade scenario and BAT rollback scenario expressed in incremental values

TABELA 4. Wymagany przyrost mocy dla scenariusza modernizacyjnego BAT oraz scenariusza wycofań BAT wyrażony w wartościach narastających

\begin{tabular}{|l|l|r|r|r|c|}
\hline & \multicolumn{1}{|c|}{ Year } & 2020 & 2025 & 2030 & 2035 \\
\hline \multirow{2}{*}{ BAT modernization scenario } & Additional power [MW] & 0 & 1,300 & 5,800 & 14,900 \\
\cline { 2 - 6 } & Total power* [MW] & 5,350 & 6,650 & 11,150 & 21,900 \\
\hline \multirow{2}{*}{ BAT phase-out scenario } & Additional power $[\mathrm{MW}]$ & 700 & 7,200 & 16,700 & 21,000 \\
\cline { 2 - 6 } & Total power* $[\mathrm{MW}]$ & 6,050 & 12,550 & 22,050 & 28,000 \\
\hline
\end{tabular}

Source: own study based on (Report 2017).

* Included the CDGU for which construction work is ongoing or is about to commence and the nuclear power plant.

The main objectives of the national energy policy are assumed by the draft of the Energy Policy of Poland until 2040 (Project 2019). The policy directions established in this project have been expanded in relation to the current policy until 2030 (Policy 2009) for the development of heating and cogeneration, the development of generation and network infrastructure and optimal use of own energy resources. The project puts a strong emphasis on the implementation of nuclear energy and puts a concrete plan to achieve this goal. The first nuclear power plant with a capacity of approximately $1.5 \mathrm{GW}$ will be launched in 2033, while the next five blocks will be commissioned every two years. The project noted a significant NPS problem, namely power losses in the system and solutions for their balancing. It is assumed that the investment in offshore wind farms will increase, support for the creation of energy clusters in local communities and the development of prosumer energy will be a support for this solution. 


\section{The forecast of national demand for power and energy}

In order to determine the forecast of the maximum national demand for power and energy by 2050 (Fig. 2 and 3), historical data of PSE SA was used regarding the average annual values of the maximum national demand for power for 2008 to 2017 and data on energy consumption in 2008-2017 (PSE 2019). In order to make the increase in the demand for power and electricity real, the reserve for the planned increase in electromobility was taken into account. The simulation assumed the following operating times of the power plant: coal 5,000 h, nuclear $6,500 \mathrm{~h}$, gas $4,000 \mathrm{~h}$, onshore wind farm $1,500 \mathrm{~h}$, offshore wind farm $2,500 \mathrm{~h}$, water $4,000 \mathrm{~h}$, biomass $4,000 \mathrm{~h}$, biogas plant 7,000 h and PV $850 \mathrm{~h}$.

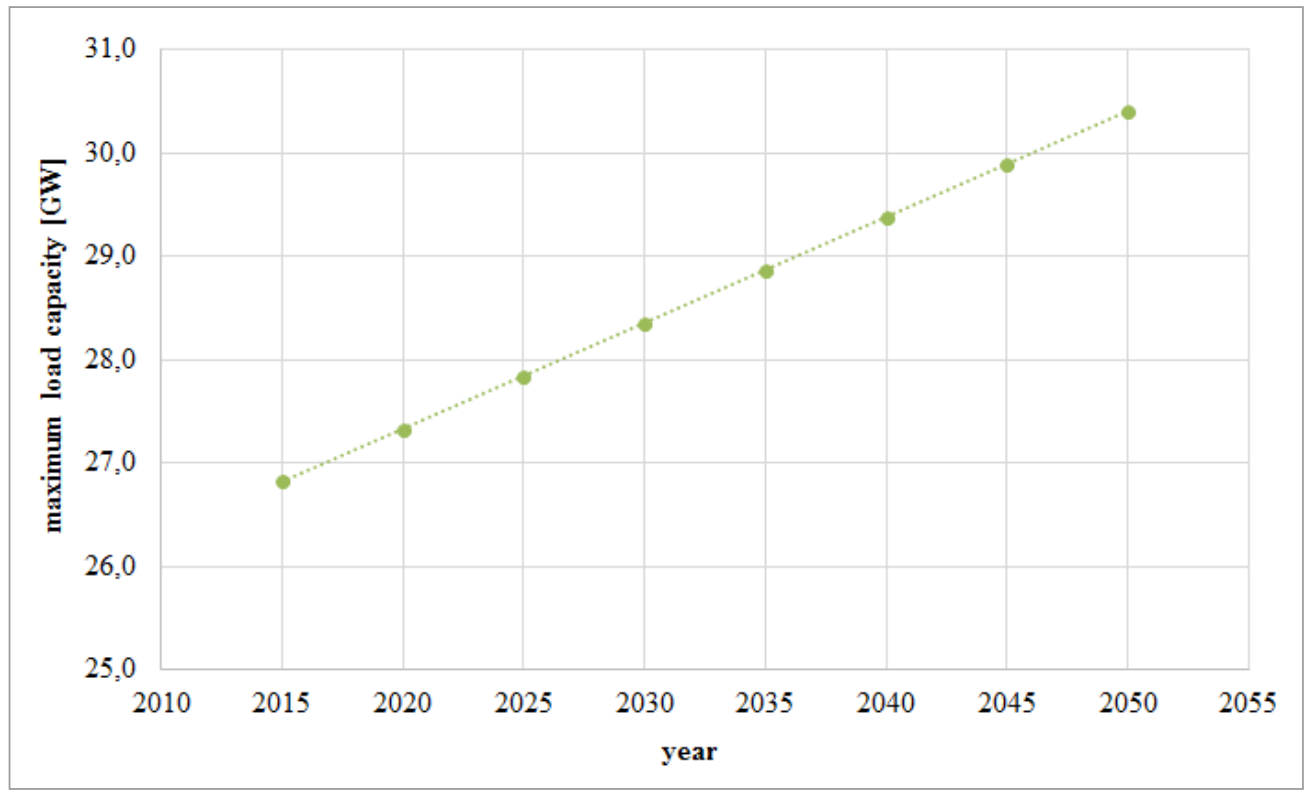

Fig. 2. Demand for maximum power in the NPS Source: own study

Rys. 2. Prognoza maksymalnego zapotrzebowanie na moc w KSE

The first proposal of the energy mix is consistent with the assumptions of the Polish Energy Policy project by 2040. According to this plan, new nuclear power plants will have been built in 2033 the first with a capacity of about 1-1.5 GW and another 5 power plants every two years. This means that at the end of 2045, the stability of the Polish Power System will provide 9 GW of nuclear power. Another proposal is to invest in offshore wind farms while extinguishing those on land. According to this document, the system will support a large amount of energy generated from solar installations, up to $20 \mathrm{GW}$ in 2040 . Renewable energy will play a greater role as system support, together with prosumer energy, which the Project places a strong emphasis on and 


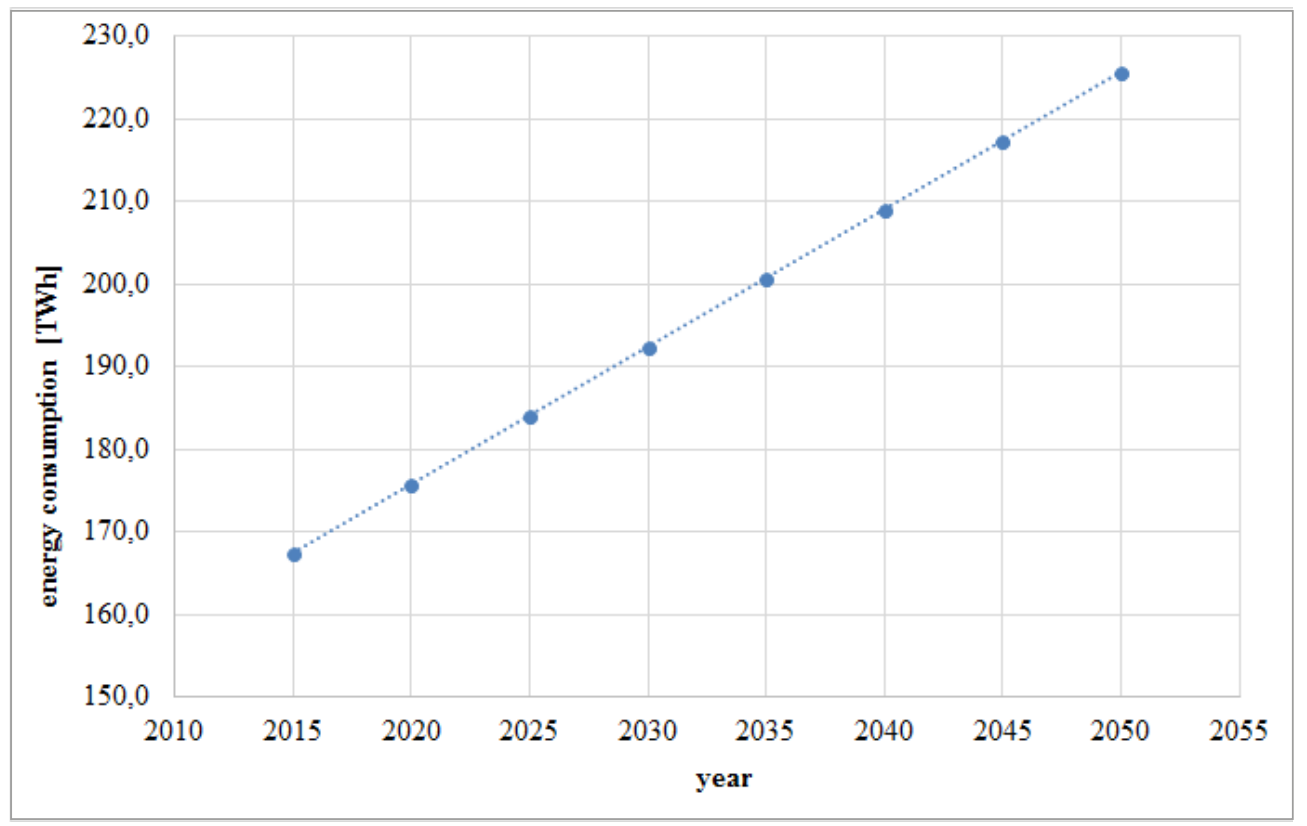

Fig. 3. Energy demand in the NPS

Source: own study

Rys. 3. Prognoza zapotrzebowania na energię w KSE

its importance for energy security. PEP2040 does not assume the resignation of energy produced in conventional power plants, but rather emphasizes the role of fossil fuels as a stabilizer of the Polish energy and economy in general. The installed power in coal-fired power plants will have been maintained at the level of $60 \%$ of the share in the mix until at least 2035 . This scenario can as be described coal-nuclear. In addition to the presented assumptions, the project highlights the importance of implementing technologies which increase the efficiency of energy generation. The mix in accordance with the above assumptions is presented in Fig. 4 and 5, respectively, for the shares of particular sources in the power and energy balance.

Another proposal of the energy mix is the assumptions of the draft of the Polish Energy Policy until 2040, but without the participation of nuclear energy. According to this proposal, nuclear construction will not be implemented in Poland. This means that at best, until the end of 2050, the last coal power plant supported by gas and wind power plants will have to provide the stability of the Polish Power System. The share of wind farms in this script must be at $16 \mathrm{GW}$ at sea, with a simultaneous increase to $9 \mathrm{GW}$ on land in 2050. According to this script, the share of photovoltaic installations in 2050 will be about $40 \mathrm{GW}$. The results of the analysis for this mix are presented in Figures 6 and 7 respectively for the shares of individual sources in the balance of power and energy. Despite the large oversizing of the system in terms of installed power by almost $50 \%$, this share of power will not ensure the adequate production of electricity and will require significant energy imports. 


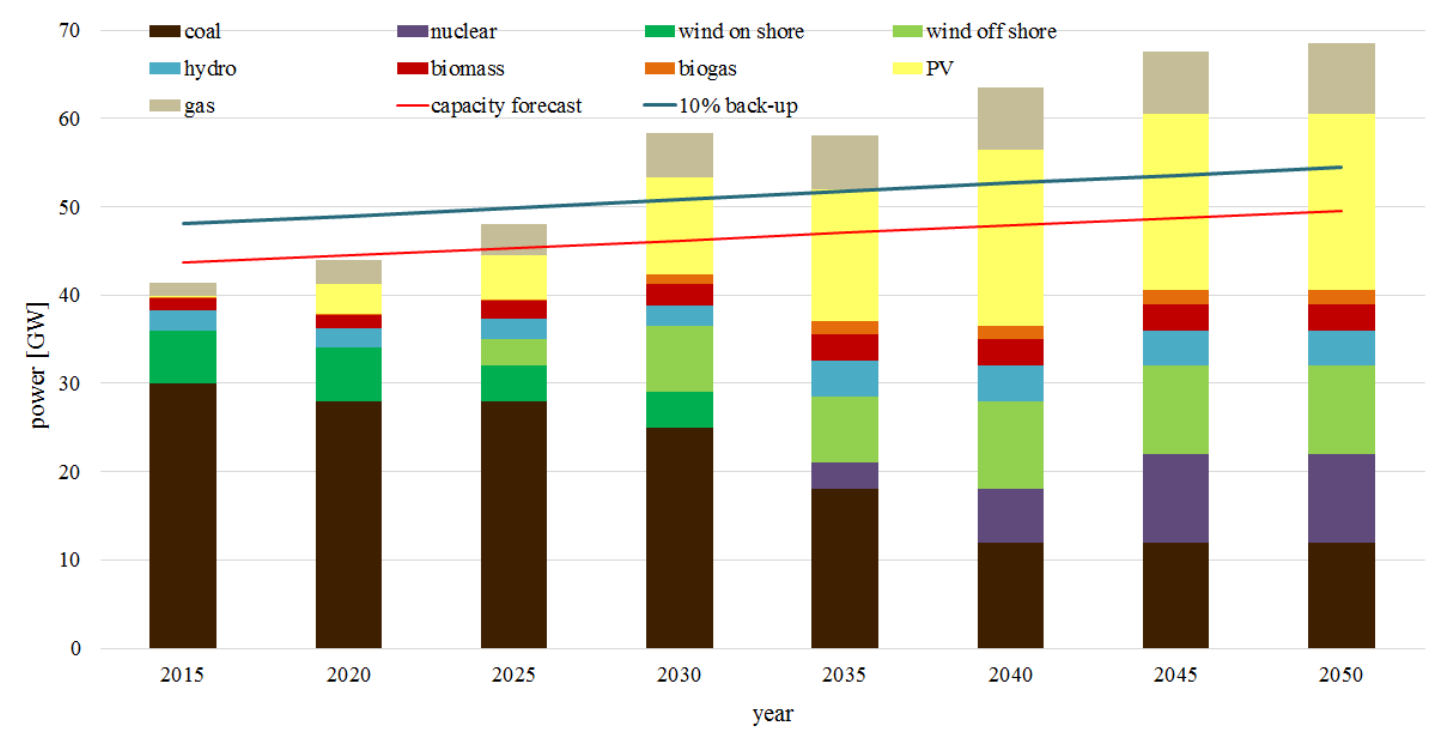

Fig. 4. Demand for power in the NPS - scenario according to PEP2040

Rys. 4. Zapotrzebowanie na moc w KSE - scenariusz zgodny z PEP2040

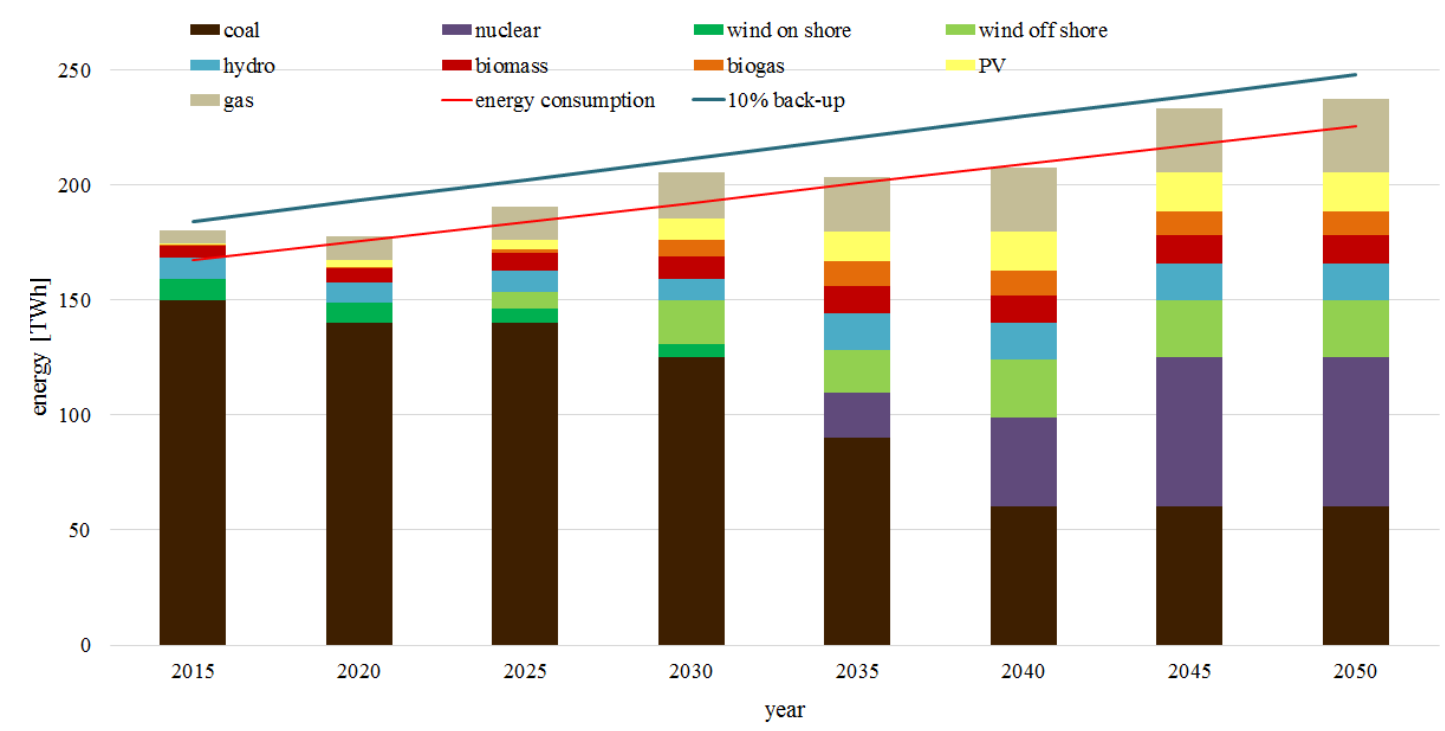

Fig. 5. Energy demand in the NPS - scenario according to PEP2040

Rys. 5. Zapotrzebowanie na energię w KSE - scenariusz zgodny z PEP2040 


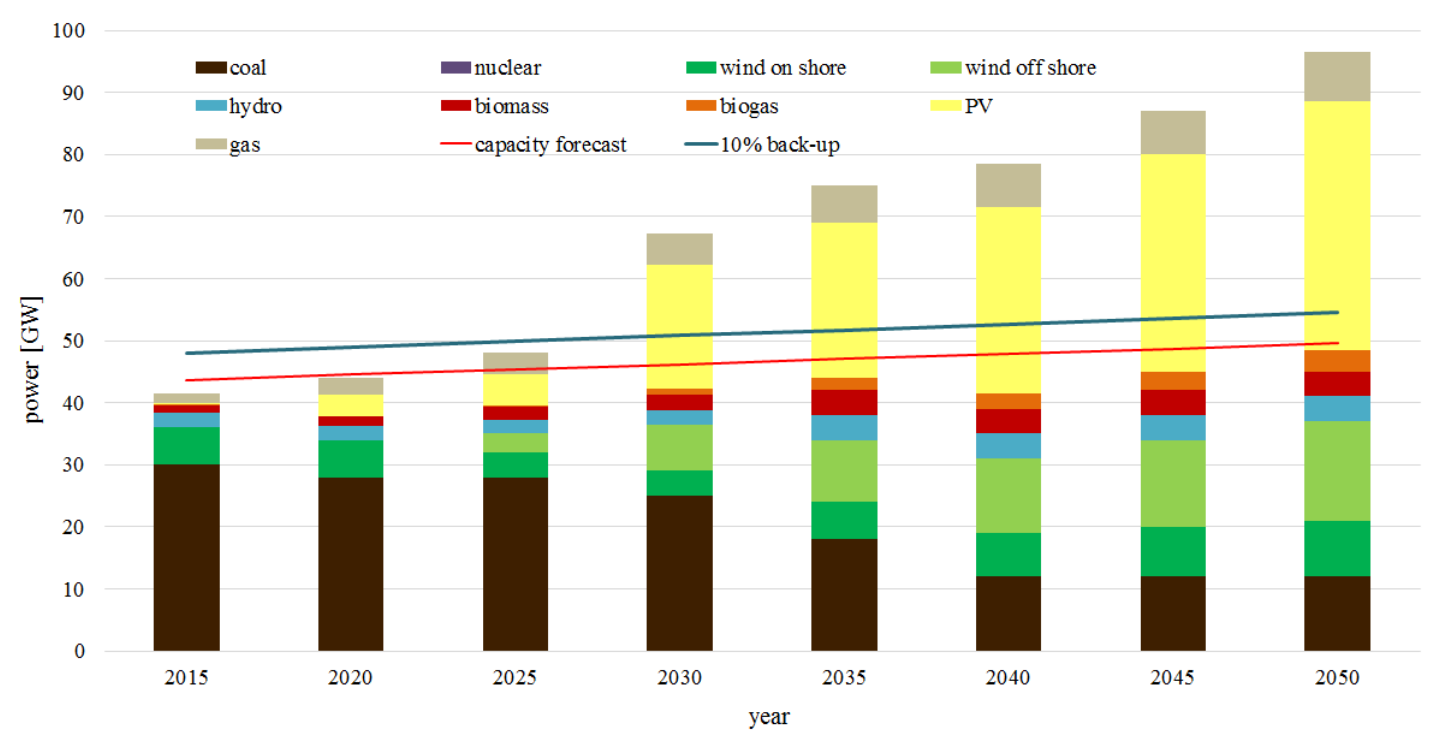

Fig. 6. Demand for power in the NPS - scenario according to PEP2040 without NPP

Rys. 6. Zapotrzebowanie na moc w KSE - scenariusz zgodny z PEP2040 bez elektrowni jądrowych

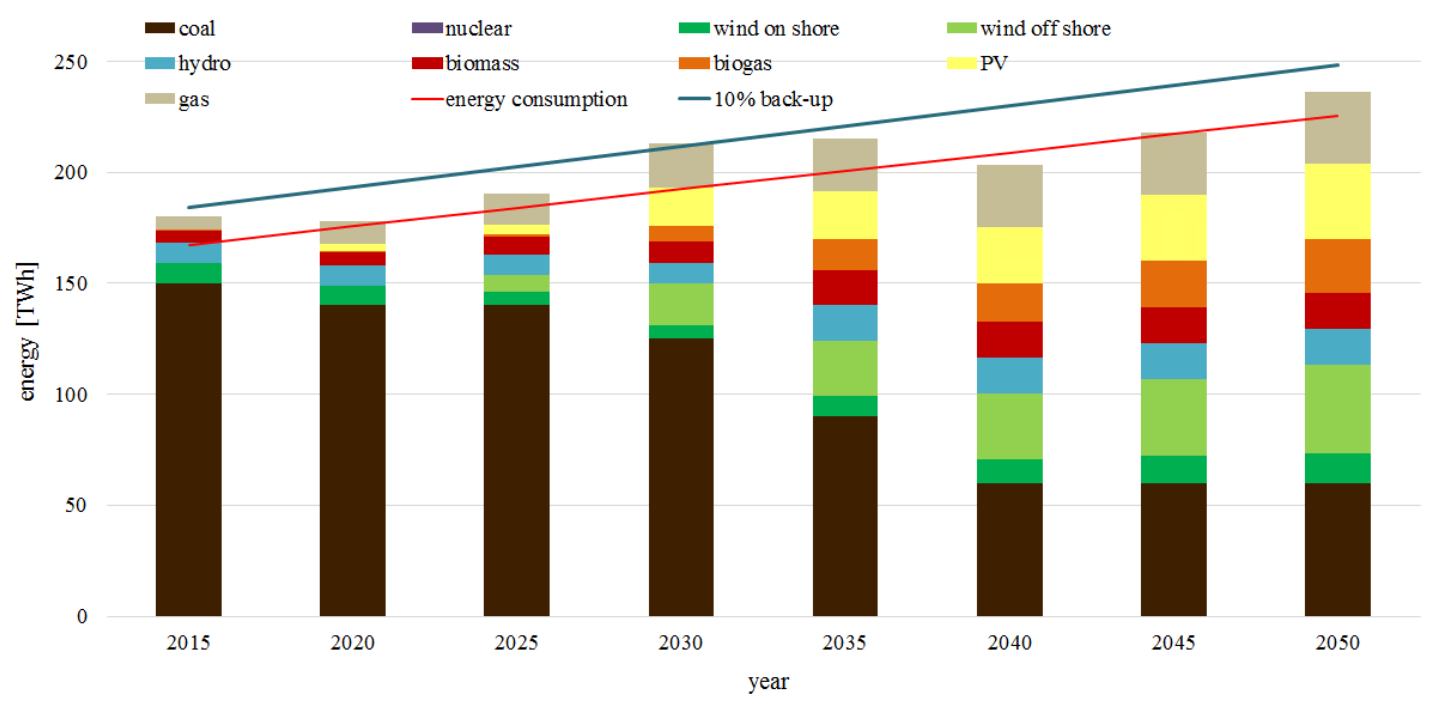

Fig. 7. Energy demand in the NPS - scenario according to PEP2040 without NPP

Rys. 7. Zapotrzebowanie na energię w KSE - scenariusz zgodny z PEP2040 bez elektrowni jądrowych 
The last proposal is the result of the analysis of the power sector in Poland, both its technical and political situation. The main aim of this proposal was to reduce the negative impact of energy on the environment while maintaining a rational approach to the costs and efficiency of RES generation. The simulation of the demand for power and electricity in the NPS assumes the most natural (in line with the exclusion schedule) withdrawal from use of coal-fired power plants, illustrated in Figures 8 and 9, but supports their lifetime as long as no stable generation sources appear in the system, that is, nuclear power plants. A significant share in the installed capacity in this proposal also applies to wind farms, both on land, due to the currently lowest investment and operating costs among renewable energy sources; as well as the one at sea, due to the longer working time translating into the stability of energy production. Wind farms will have been supplemented with solar farms and energy production from biomass and biogas plants. An important assumption for beneficial cooperation of the discussed technologies will be investing in increasing the efficiency of electricity production and in prosumer energy, which can play a key role in supporting the stability of the NPS and increase the share of renewable energy in the final energy balance.

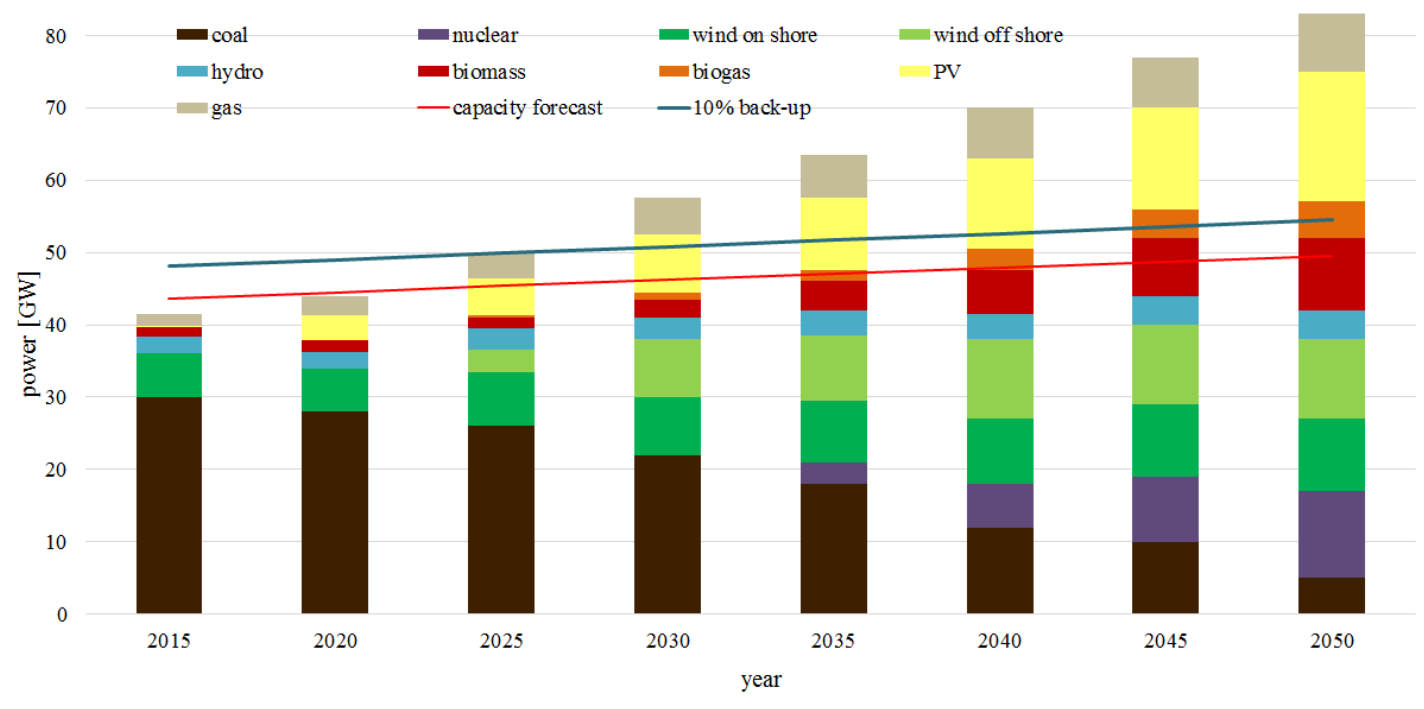

Fig. 8. Demand for power in the NPS - author's scenario

Rys. 8. Zapotrzebowanie na moc w KSE - scenariusz autorski 


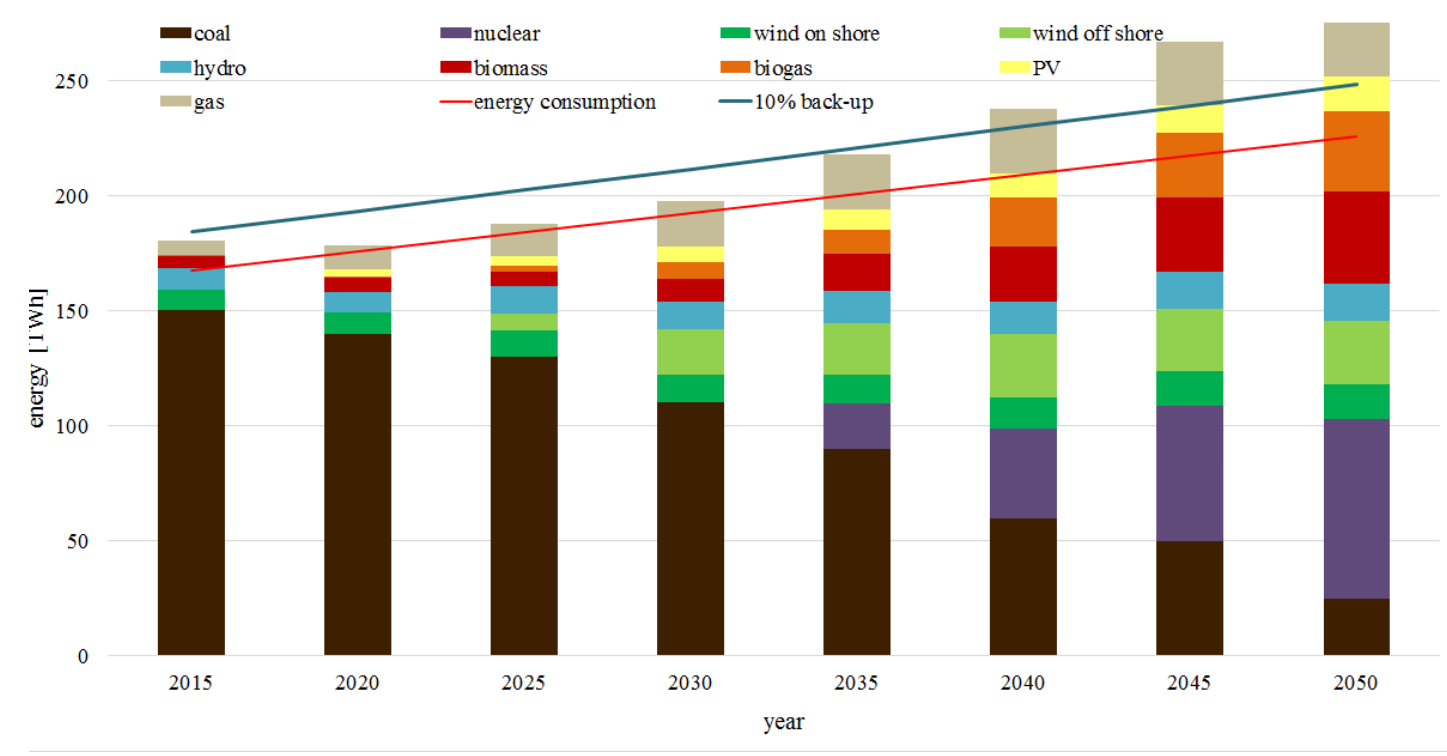

Fig. 9. Energy demand in the NPS - author's scenario

Rys. 9. Zapotrzebowanie na energię w KSE - scenariusz autorski

\section{Summary}

In the near future, the national power system will face a change in the energy strategy due to the shrinking fuel resources and the growing impact of environmental conditions. Limiting emissions, especially $\mathrm{CO}_{2}$ will be crucial. However this shouldn't be achieved by drastically delineating coal from the Polish energy mix. The high share of fuels coming mainly from domestic sources should be a guarantee of Poland's energy security in the coming years. The choice of technology for new generation sources in the longer term needs to be considered, however it must be based on an economic criterion. In the future, the domestic energy mix must be characterized by very high flexibility, because the share of renewable energy sources in the energy system will constantly increase. Power plants operating in the energy system should be characterized by high efficiency and a low emission of pollutants. In addition, high flexibility power plants are needed in the system to cover variable peak demand or to cooperate with renewable energy sources and compensate for temporary changes related to variable wind power or insolation.

The assumptions and construction of the energy mix, in other words, the path of energy development of the state, is an extremely difficult task. After considering each generation source, many aspects need to be considered. Each technology brings both benefits and new problems to solve. After creating the energy mix, a significant number of variables should be taken into 
account, including the impact on the entire economy, cost analysis, environmental impact, social moods and much more. However, to ensure the demand for power and electricity resigning the environmentally harmful presence of carbon sources, it will be necessary to find a source of electricity generation that will ensure production stability. The answer is unequivocal, this source may be nuclear energy. However, before its implementation begins, in the most optimistic case, consistent with the assumptions of PEP2040, at least until 2033, the stability of the Polish energy sector must be supported by the coal-fired power plants. This should, of course, be the at smallest environmental cost, meaning it is necessary to develop renewable energy sources, especially wind, both at sea and on land.

\section{References}

Assurance 2014. Assurance of generation capacities in conventional power generation (Zapewnienie mocy wytwórczych w elektroenergetyce konwencjonalnej). Department of Economy, Treasury and Privatisation (in Polish).

Best 2016. Best Available Techniques (BAT) Reference Document for Large Combustion Plants, JOINT RESEARCH CENTRE Institute for Prospective Technological Studies Sustainable Production and Consumption Unit European IPPC Bureau, Final Draft, 2016.

JANUSZ, et al. 2017 - JANUSZ, P. SZCZERBOWSKI, R. and ZALESKI, P. 2017. Important aspects of Polish energy security (Istotne aspekty bezpieczeństwa energetycznego Polski). Warsaw, Texter, pp. 132 (in Polish).

OLKUSKI, T. 2015. $\mathrm{CO}_{2}$ emission allowance trading in the European Union and its impact on combating climate change (Wptyw handlu uprawnieniami do emisji $\mathrm{CO}_{2} w$ Unii Europejskiej na przeciwdziałanie zmianom klimatu). Polityka Energetyczna - Energy Policy Journal Vol. 18, Issue 3, pp. 87-98 (in Polish).

Plan 2015. Development Plan for Meeting Current and Future Electricity Demand for 2016-2025 (Plan rozwoju w zakresie zaspokojenia obecnego i przyszłego zapotrzebowania na energię elektryczna na lata 2016-2025). PSE S.A., Konstancin-Jeziorna 2015 (in Polish).

Policy 2009. The Energy Policy of Poland until 2030 (Polityka energetyczna Polski do 2030 roku). Document adopted by the Council of Ministers on 10 November 2009 (in Polish).

Project 2019. Project of Polish Energy Policy until 2040 (Projekt Polityki energetycznej Polski do 2040 roku), Ministry of Energy, Warsaw 2019 (in Polish).

PSE 2019. PSE S.A. 2019 - [Online] www.pse.pl [Accessed: 10.07.2019] (in Polish).

Report 2017. Report on the results of the monitoring of security of energy supply for the period from 1 January 2015 to 31 December 2016 (Sprawozdanie z wyników monitorowania bezpieczeństwa dostaw energii elektrycznej za okres od dnia 1 stycznia 2015 r. do dnia 31 grudnia 2016 r.), Warsaw 2017 [Online] https://www.gov.pl/documents/ [Accessed: 01.07.2019] (in Polish)

Strategy 2017. Strategy for Responsible Development until 2020 (Strategia na Rzecz Odpowiedzialnego Rozwoju do roku 2020) (in Polish). Warsaw 2017 [Online] https://www.gov.pl/web/inwestycje-rozwoj/ informacje-o-strategii-na-rzecz-odpowiedzialnego-rozwoju [Accessed: 01.07.2019] (in Polish)

SzCZERBowsKi, R. and CERAN, B. 2017. Poland's Energy Policy in the aspect of the challenges of the $21^{\text {st }}$ century (Polityka energetyczna Polski w aspekcie wyzwań XXI wieku). Polityka Energetyczna - Energy Policy Journal Vol. 20, Issue 3, pp. 17-28 (in Polish). 


\title{
Propozycja miksu energetycznego w kontekście zmian polityki energetycznej Polski
}

\begin{abstract}
Streszczenie
Przyszłość i rozwój energetyki to jeden z najważniejszych problemów zarówno w polityce krajowej, jak i światowej. Odpowiedzialność sektora energetycznego za zmiany klimatyczne na Ziemi oraz troska o zapewnienie wystarczających ilości energii w najbliższych latach, stanowią główne wyzwania, jakie stoją obecnie przed energetyką. W artykule przedstawiono stan obecny krajowego sektora wytwórczego. W perspektywie najbliższych kilkunastu lat dalej będzie się on opierał na energetyce konwencjonalnej, jednak z coraz większym udziałem źródeł odnawialnych. Konieczne jest jednak opracowanie nowej strategii energetycznej, która wskaże, w jakim kierunku będzie zmierzać krajowy sektor wytwórczy. Jest to tym bardziej istotne, że nowe uwarunkowania prawne związane szczególnie z ochroną środowiska przyrodniczego zdecydowanie ograniczają stosowanie paliw konwencjonalnych w energetyce. Ponadto, w artykule omówiono najważniejsze aspekty uwzględniane podczas tworzenia miksu energetycznego dla kraju. Pierwszym z nich jest opis aktualnego stanu sektora energetycznego w Polsce, udział procentowy poszczególnych technologii w aktualnym bilansie mocy i energii elektrycznej oraz stan techniczny infrastruktury sektora wytwórczego. Na podstawie analizy danych historycznych Polskich Sieci Elektroenergetycznych SA, dotyczących wielkości obciążenia oraz zużycia energii przeprowadzono matematyczną estymację zapotrzebowania na moc elektryczną oraz prognozę zużycia energii elektrycznej. Wyznaczone prognozy zostały użyte do przeprowadzenia symulacji wypełnienia zapotrzebowania na moc oraz energię w Krajowym Systemie Elektroenergetycznym. Przedstawiono kilka możliwych scenariuszy uwzględniających różne spojrzenia na sektor energetyczny w Polsce.
\end{abstract}

SŁOWA KLUCZOWE: polityka energetyczna, bezpieczeństwo energetyczne, miks energetyczny 